\title{
ANALISIS IMPLEMENTASI STRATEGI DIFERENSIASI \\ DAN PENGAMATAN LINGKUNGAN UNTUK MENCIPTAKAN \\ KEUNGGULAN BERSAING PADA PT BPRS (MICRO BANKING SYARIAH) \\ NIAGA MADANI DI SELURUH WILAYAH SULAWESI SELATAN
}

\author{
Oleh \\ SYAMSUL ALAM \\ Dosen Kopertis Wilayah IX Sulawesi Dpk STIE Nobel Indonesia Makassar
}

\begin{abstract}
Based on the ANOVA F test statistic obtained or calculated $F$ value of 10.642 with a probability level of 0.000 . The probability is much smaller than 0.05 , then the regression model can be used to predict the competitive advantage or it can be said that the implementation of variable differentiation strategies, and environmental Pengamtan together significantly influence variables Competitive Advantage.

T-test results on differentiation strategy implementation variables produce t count of 8.115 and a significance of $0.000 .8115 \mathrm{~T}$ count $>t$ table whose value is 1.706 with a significance level of 0.000 is less than 0.05 , it can be seen that the hypothesis that implementation of differentiation strategy has positive influence on acceptable Competitive Advantage

Partial effects significance test results (t test) in variable environments Pengamtan produce t count of 5,720 with a significance level of 0.000. 5,720 T count $>$ t table whose value is 1.706 with a significance level of $0.000<0.05$, it can be seen that the hypothesis that Pengamtan positive effect on the environment is acceptable Competitive Advantage.
\end{abstract}

Keywords : Differentiation Strategy, Environmental Observations, and Competitive Advantage

\section{PENDAHULUAN}

Dinamika persaingan bisnis antar perusahaan yang ada kini telah memasuki era persaingan yang semakin kompetitif. Seiring dengan perkembangan ilmu pengetahuan dan teknologi yang semakin maju, cepat ataupun lambat suatu perusahaan perlu untuk menyesuaikan model manajemen stratejiknya. Dalam hal ini suatu perusahaan yang siap mengadopsi dan melakukan penyesuaian manajemen stratejiknya dengan kondisi perubahan ini, akan mampu bertahan dalam persaingan. Sehingga bukan menjadi masalah yang penting, apakah perusahan tersebut baru atau tidak, namun satu hal perlu disadari bahwa kunci keberhasilan terletak pada kemampuan perusahaan untuk mengambil kebijakan stratejik yang tepat untuk menghadapi persaingan.

Konsep manajemen stratejik yang baru menekankan pada kepentingan atau kepuasan konsumen dari perspektif kompetitor. Dengan berfokus pada kepentingan konsumen, perusahaan harus membangun posisi kompetitif yang kuat. Beberapa perusahaan besar selalu berupaya mewujudkan posisi kompetitif yang kuat melalui jalinan kerjasama dengan para pemasok mereka. Posisi kompetitif yang kuat hanya dapat diciptakan dengan membangun keunggulan kompetitif yang kuat. Tanpa posisi ini, akan sulit bagi perusahaan untuk dapat bertahan dalam persaingan. Keunggulan kompetitif dapat dibangun melalui banyak cara, antara lain dengan menciptakan implementasi strategi diferensiasi dan pengamatan lingkungan. Hal ini menunjukkan bahwa keunggulan kompetitif dapt dicapai dengan mengarahkan strategi perusahaan yang berorientasi pada konsumen atau pelanggan.

Pada perusahaan jasa, terutama dalam bidang perbankan, keunggulan bersaing seringkali diupayakan dalam bentuk harga yang unggul, akan tetapi menurut MacMillan dan McGrath (1997) 
dalam penelitiannya berpendapat bahwa strategi diferensiasi dibuat berdasarkan perbedaan dan menawarkan kepada para pembeli sesuatu yang bernilai yang tidak dimiliki oleh para pesaing.

Diferensiasi merupakan salah satu keunggulan bersaing yang bisa dimiliki perusahaan. Perusahaan melakukan diferensiasi jika perusahaan dapat memiliki keunikan dibandingkan para pesaingnya dalam sesuatu yang dinilai penting oleh pembeli. Cross (1999) dalam penelitiannya menyatakan bahwa perusahaan yang menerapkan strategi diferensiasi menciptakan dan memproduksi sesuatu yang dianggap unik oleh para konsumennya dan dengan demikian strategi tersebut mendorong terciptanya minat masuk mahasiswa. Alasan lain terciptanya minat masuk mahasiswa adalah karena produk yang dihasilkan perusahaan dipandang memiliki nilai yang tinggi oleh para konsumen.

Yasai Ardekani dan Nystrom (Beal, 2000), mengemukakan bahwa scope dan frequency dari pengamatan lingkungan dapat mempengaruhi kemampuan perusahaan dalam menyelaraskan strategi bersaingnya dengan lingkungan. Pengamatan yang sering dilakukan terhadap bagian-bagian dari lingkungan menyediakan informasi mutakhir bagi perusahaan dan memudahkannya untuk menguji keakuratan dari informasi, juga untuk lebih cepat beradaptasi terhadap perubahan kondisi lingkungan dibanding dengan yang jarang melakukan pengamatan.

Pengalaman menunjukkan bahwa peluang maupun ancaman dapat timbul dari berbagai sumber (Jackson dan Dutton, dalam Beal, 2000). Dengan demikian, memperoleh informasi tentang beberapa sektor atau bagian yang berbeda dapat memberikan informasi yang relevan sebagai upaya menyelaraskan strategi bersaing perusahaan dengan kondisi lingkungan. Oleh karena itu, dengan menjaga informasi antar bagian dari lingkungan dapat membuat perusahaan memperoleh keunggulan bersaing atau menjaga posisi pasarnya.

BPRS (Micro Banking Syariah) Niaga Madani adalah BPRS terbesar di wilayah timur Indonesia, baik dalam volume bisnis dan layanan jaringan kantor. Bahkan hingga 2011, BPRS Niaga madani terdaftar sebagai Niaga BPRS satunya Madani yang memiliki jaringan kantor di sejumlah kabupaten / kota di Sulawesi Selatan.

Jaringan cabang BPRS Niaga Madani dapat ditemukan di Sengkang, Gowa dan Makassar, sementara kantor kas di Maros, Bone, Soppeng dan dua unit di Makassar. Semua jaringan kantor dilengkapi dengan aplikasi sistem informasi perbankan online layanan teknologi, sehingga pelanggan dapat melakukan transaksi secara real time.

BPRS (Micro Banking Syariah) Niaga Madani, sebelumnya dikenal sebagai fastaqbiqul khaerat, telah bergabung dengan multi Niaga Group (MNG) sejak september 2002. Sebagai hasil dari pengalaman dan reputasi dari kelompok usaha ini dalam industri keuangan mikro, BPRS (Micro Banking Syariah) Niaga Madani mencatat pertumbuhan yang cukup positif dari tahun ke tahun.

Pertumbuhan bisnis yang tidak dapat dipisahkan dari pengembangan manajemen sumber daya manusia yang selalu menjadi perhatian bagi BPRS (Micro Banking Syariah) Niaga Madani. Sampai semester kedua tahun 2011 BPRS (Micro Banking Syariah) Niaga Madani telah mencatat aset IDR58 miliar dengan jumlah nasabah mencapai 6000 
rekening.www/http/bprs/mbs/niagamada ni.co.id.

Dalam meningkatkan dana pihak ketiga, BPRS (Micro Banking Syariah) Niaga Madani memiliki sejumlah produk unggulan sebagai contoh Tabungan Madani, tabungan pendidikan, umrah, qurban, hari raya, tabungan dan deposito walimah dengan tingkat setara dalam tingkat yang sangat kompetitif. sedangkan BPRS madani produk pembiayaan Niaga seperti modal kerja pembiayaan dengan pola bagi hasil (mudarabah) dan pembiayaan murabahah untuk pembelian mobil, sepeda motor, atau pembiayaan konsumtif lainnya.

\section{RUMUSAN MASALAH}

Berdasarkan latar belakang di atas bahwa perusahaan dapat menguasai pasar dengan implementasi strategi diferensiasi, dan pengamatan lingkungan. Adapun rumusan masalah adalah :

1. Apakah implementasi strategi diferensiasi, dan pengamatan lingkungan secara bersama-sama berpengaruh terhadap keunggulan bersaing pada PT. BPRS (Micro Banking Syariah) Niaga Madani di seluruh wilayah Sulawesi Selatan?

2. Apakah implementasi strategi diferensiasi secara parsial berpengaruh dominan terhadap keunggulan bersaing pada PT. BPRS (Micro Banking Syariah) Niaga Madani di seluruh wilayah Sulawesi Selatan?

\section{TUJUAN PENELITIAN} lain :

Adapun tujuan penelitian antara

1. Untuk menganalisis implementasi strategi diferensiasi, dan pengamatan lingkungan secara bersama-sama berpengaruh terhadap keunggulan bersaing pada PT. BPRS (Micro
Banking Syariah) Niaga Madani di seluruh wilayah Sulawesi Selatan.

2. Untuk menganalisis implementasi strategi diferensiasi secara parsial berpengaruh dominan terhadap keunggulan bersaing pada PT. BPRS (Micro Banking Syariah) Niaga Madani di seluruh wilayah Sulawesi Selatan.

\section{LANDASAN TEORI}

\section{A. Implementasi Strategi Diferensiasi}

Implementasi Strategi adalah jumlah keseluruhan aktivitas dan pilihan yang dibutuhkan untuk dapat menjalankan perencanaan strategis. Implementasi strategis merupakan proses dimana beberapa strategi dan kebijakan diubah menjadi tindakan melalui pengembangan program, anggaran dan prosedur. Walaupun implementasi biasanya baru dipertimbangkan setelah strategi dirumuskan, akan tetapi implementasi merupakan kunci suksesnya dari manajemen strategic. Menurut Crown Dirgantoro (2001), "strategi berasal dari bahasa Yunani yang berarti kepemimpinan dalam ketentaraan".

Menurut Agustinus Sri Wahyudi (1996), "strategi berarti "generalship" atau sesuatu yang dikerjakan oleh para jenderal perang dalam membuat rencana untuk memenangkan perang“.

Sedangkan menurut Husain Umar (2002), "strategi adalah hal menempatkan arah kepada manajemen dalam arti orang tentang sumber daya di dalam bisnis dan tentang bagaimana mengidentifikasikan kondisi yang memberikan keuntungan terbaik untuk membantu memenangkan persaingan didalam pasar".

Dari pernyataan diatas penulis mendefinisikan tentang strategi yaitu suatu alat yang digunakan oleh para jenderal perang dalam menerapkan taktik perang untuk mengelola para tentara dalam melakukan mobilisasi pasukannya 
dengan jumlah yang besar, dan bagaimana mengkoordinasikan komando yang jelas, sehingga dapat memenangkan perang. Akan tetapi pengertian strategi dari Husain Umar menjelaskan tentang penerapan strategi pada dunia usaha yang mengandung dua komponen, yaitu :

1.Future Intention (tujuan masa depan), dan

\section{Competitive advantage (keunggulan bersaing).}

Dengan demikian penulis dapat mengambil kesimpulan tentang definisi strategi yaitu suatu alat bantu dalam mencapai tujuan perusahaan dengan harapan perusahaan dapat menciptakan keunggulan bersaing pada bidang usahanya dengan para persaingnya. Bentuk strategi dapat bervariasi dari satu industri ke industri lain, dari satu perusahaan ke perusahaan lain. Sehingga setiap perusahaan mempunyai strategi sendiri yang berbeda dengan para pesaing. Namun ada sejumlah strategi yang umum dapat diterapkan pada berbagai bentuk industri dan ukuran organisasi/perusahaan, yang dikenal dengan "Strategi Generik".

Menurut M. Porter (2007), ada 3 pendekatan strategi generik dalam menanggulangi kekuatan persaingan yang secara potensial akan berhasil mengungguli perusahaan lain dalam suatu industri, yaitu :

1. Keunggulan biaya menyeluruh

2. Diferensiasi

3. Fokus

MacMillan dan McGrath (1997) dalam penelitiannya berpendapat bahwa strategi diferensiasi dibuat berdasarkan perbedaan dan menawarkan kepada para pembeli sesuatu yang bernilai yang tidak dimiliki oleh para pesaing.

Cross (1999) dalam penelitiannya menyatakan bahwa perusahaan yang menerapkan strategi diferensiasi menciptakan dan memproduksi sesuatu yang dianggap unik oleh para konsumennya dan dengan demikian strategi tersebut mendorong terciptanya minat masuk mahasiswa. Hal ini terjadi karena para konsumen percaya bahwa mereka membeli produk yang unik yang tidak dapat ditiru dengan mudah oleh para pesaing perusahaan. Alasan lain terciptanya minat masuk mahasiswa adalah karena produk yang dihasilkan perusahaan dipandang memiliki nilai yang tinggi oleh para konsumen.

Menurut Getz dan Sturdivant (1989) ada beberapa pendekatan yang dapat digunakan perusahaan untuk mengembangkan strategi diferensiasi yang efektif. Strategi tersebut dapat difokuskan pada biaya, struktur industri, pilihanpilihan yang ada dalam pasar, atau kemampuan internal perusahaan.

Porter (1993) menyatakan bahwa diferensiasi dipahami melalui sejumlah kegiatan spesifik yang dilakukan perusahaan dan pengaruh kegiatan tersebut terhadap pembeli. Diferensiasi tumbuh dari rantai nilai perusahaan. Setiap aktivitas nilai yang ada dalam perusahaan merupakan sumber yang potensial bagi penciptaan keunikan bagi perusahaan. Sejumlah faktor yang membantu diferensiasi dapat diperoleh dari cakupan bersaing yang luas, yaitu kemudahan pemeliharaan bagi pembeli jika dibandingkan produk sejenis yang ada di segmen pasar dan keunggulan kompatibilitas dibandingkan dengan produk lain. Sebagian besar manfaat tadi hanya dapat dicapai jika perusahaan melakukan aktivitas rantai nilainya secara konsisten dan terkoordinasi. Jika perusahaan mengelola hubungan dengan pembeli melalui rantai nilai perusahaan secara konsisten dan berkesinambungan, maka keuntungan yang diperoleh adalah perusahaan akan memperoleh keunggulan bersaing yang berkesinambungan dan pada akhirnya bisnis perusahaan akan berkembang. 
Diferensiasi

biasanya membutuhkan biaya tinggi. Perusahaan seringkali harus mengeluarkan biaya untuk menjadi unik karena untuk mencapai keunikan, perusahaan harus melaksanakan sejumlah aktivitas nilai secara lebih baik daripada para pesaingnya. Demikian pula, mendiferensiasikan diri dengan cara memberikan ciri lebih banyak kepada produk barangkali membutuhkan biaya lebih tinggi daripada mendiferensiasikan diri dengan cara memberi produk cirri yang berbeda-beda tetapi lebih disukai (Porter, 1993).

\section{B. Pengamatan Lingkungan}

Pengamatan lingkungan merupakan akuisisi dan penggunaan informasi mengenai kejadian-kejadian, tren-tren, dan hubungan-hubungan dalam suatu lingkungan eksternal organisasi, di mana merupakan pengetahuan yang akan dapat membantu manajemen dalam merencanakan tindakan-tindakan di masa mendatang (Choo, 1999). Perusahaan menuju lingkungan masa depan yang tidak pasti, di mana lingkungan usaha menjadi mudah berubah dan para manajer harus sanggup beradaptasi. Perusahaan yang dapat beradaptasi dengan lingkungannya agar dapat bertahan dan berhasil dengan baik. Keputusan strategik harus diambil untuk kapan dan bagaimana menghadapi perubahan-perubahan.

Para manajer harus secara jelas mengetahui perubahan apa yang telah terjadi, apa

yang akan terjadi di pasar dan bagaimana hal tersebut secara potensial mempengaruhi kegiatan perusahaan (Xu dan Kaye, 1995).

Perusahaan melakukan pengamatan terhadap lingkungan supaya memahami kekuatan perubahan eksternal sehingga mereka dapat mengembangkan respon yang efektif untuk perbaikan di masa mendatang. Memilih lingkungan yang tepat untuk diamati merupakan suatu masalah. Manajer hanya tertarik pada lingkungan yang mempengaruhi pengambilan keputusan.
Memang perlu untuk selektif dalam memilih, tapi harus yakin bahwa tetap dijaga kecukupannya untuk menghindari kehilangan sinyal-sinyal penting. (Xu dan Kaye, 1995).

Ahituv et.al (dalam Xu, 1999) mengemukakan salah satu ciri utama dari pemasaran berorientasi strategik adalah adanya interaksi dengan lingkungan eksternal dengan mendapatkan sinyalsinyal penting. Lebih lanjut $\mathrm{Xu}$ juga berpendapat bahwa dengan memperoleh pemahaman yang sistematis tentang perubahan yang terjadi di pasar dapat memudahkan perusahaan secara cepat dan tepat menyesuaikan posisi pasar dan strateginya untuk memaksimalkan kepuasan pelanggan, sembari mempertahankan keunggulan bersaing di lingkungannya.

Lebih lanjut Beal (2000) mengemukakan dua ukuran yang seringkali digunakan dalam melakukan pengamatan yaitu seberapa sering para manajer memonitor lingkungan (frequency), dan seberapa luas cakupannya (scope).

Frequency dan scope merupakan dua ciri dari proses pengamatan (Fahr, Hoffman, dan Hegarty, 1984; dalam Beal, 2000). Frequency mengacu pada seberapa seringnya suatu perusahaan melakukan pengamatan terhadap lingkungannya dan juga diasosiasikan dengan ketepatan waktu, relevansi, dan banyaknya informasi yang dapat dikumpulkan oleh perusahaan tentang berbagai bagian seperti pelanggan, pemasok, dan pesaing dari lingkungan kerja (Daft et. al., dalam Beal, 2000). Scope mengindikasikan banyaknya bagian yang berbeda dari lingkungan yang diamati oleh perusahaan.

Dengan melakukan pengamatan lingkungan terhadap bagian-bagiannya dapat memberi informasi kepada perusahaan tentang berbagai hal dan tren yang mempengaruhi survival dan kemakmuran perusahaan. Sebagai misal, tindakantindakan 
pesaing yang kompetitif (pengenalan produk baru, perubahan harga), permintaanpermintaan pelanggan, keinginan dan kebiasaan membeli, kemajuan teknologi, dan perkembangan ekonomi, di mana ini semua memerlukan respons yang adaptif dari perusahaan.

Yasai-Ardekani dan Nystrom (Beal, 2000), mengemukakan bahwa scope dan frequency dari pengamatan lingkungan dapat mempengaruhi kemampuan perusahaan dalam menyelaraskan strategi bersaingnya dengan lingkungan. Pengamatan yang sering dilakukan terhadap bagian-bagian dari lingkungan menyediakan informasi mutakhir bagi perusahaan dan memudahkannya untuk menguji keakuratan (verify the accuracy) dari informasi, juga untuk lebih cepat beradaptasi terhadap perubahan kondisi lingkungan dibanding dengan yang jarang melakukan pengamatan. Seringnya pengamatan juga memposisikan perusahaan untuk selalu mengikuti kejadian-kejadian dan tren dalam lingkungan.yang dapat mengancam eksistensi perusahaan atau dapat pula menawarkan peluang-peluang baru untuk dieksploitasi.

\section{Keunggulan Bersaing}

Keunggulan bersaing (competitive advantage) adalah jantung kinerja perusahaan dalam pasar bersaing. Dewasa ini pentingnya keunggulan bersaing tidak mungkin diabaikan lagi. Keunggulan bersaing pada dasarnya tumbuh dari nilai atau manfaat yang dapat diciptakan perusahaan bagi para pembelinya yang lebih dari biaya yang harus dikeluarkan perusahaan untuk menciptakannya. Nilai atau manfaat inilah yang sedia dibayar oleh pembeli, dan nilai yang unggul berasal dari penawaran harga yang lebih rendah ketimbang harga pesaing untuk manfaat setara atau penawaran manfaat unik yang melebihi harga yang ditawarkan (Porter, 1993).

Day dan Wensley (dalam Cravens, 1996) mengemukakan bahwa keunggulan bersaing seharusnya dipandang sebagai suatu proses dinamis ketimbang sebagai hasil akhir. Dikemukakan pula sebagai suatu proses yang terdiri atas sumber keunggulan, keunggulan posisi, dan prestasi hasil akhir serta investasi laba untuk mempertahankan keunggulan. Perusahaan harus melakukan tindakan menyeluruh untuk menghasilkan keunggulan bersaing yang berkesinambungan, agar lebih unggul dari pesaing

Menurut Crown Dirgantoro dalam (2001) bahwa, "keunggulan bersaing merupakan perkembangan dari nilai yang mampu diciptakan perusahaan untuk pembelinya".

Menurut Agustinus Sri Wahyudi (1996) mendefinisikan keunggulan bersaing, adalah : "Sesuatu yang memungkinkan sebuah perusahaan memperoleh keuntungan yang lebih tinggi dibandingkan dengan rata-rata keuntungan yang diperoleh pesaing dalam industri. Semakin kuat keunggulan yang dimiliki akan semakin tinggi keuntungan yang diperoleh perusahaan dan begitu pula sebaliknya".

Berdasarkan kedua definisi diatas maka keunggulan bersaing tidak dapat dipahami dengan memandang perusahaan sebagai satu keseluruhan. Keunggulan bersaing berasal dari banyak aktivitas berlainan yang dilakukan perusahaan dalam mendesain, memproduksi, memasarkan, menyerahkan, mendukung produknya. Masing - masing aktivitas dapat mendukung posisi biaya relatif perusahaan dan menciptakan dasar untuk diferensiasi.

\section{HIPOTESIS}

Hipotesis merupakan jawaban sementara terhadap rumusan masalah penelitian yang bertujuan mengarahkan dan memberikan pedoman dalam pokok permasalahan serta tujuan penelitian. Maka dari uraian masalah yang ada, dapat 
dimunculkan suatu hipotesis penelitian sebagai berikut :

1. Diduga bahwa implementasi strategi diferensiasi, dan pengamatan lingkungan secara bersama-sama berpengaruh signifikan terhadap keunggulan bersaing pada PT. BPRS (Micro Banking Syariah) Niaga Madani di seluruh wilayah Sulawesi Selatan.

2. Diduga bahwa implementasi strategi diferensiasi secara parsial berpengaruh paling dominan terhadap keunggulan bersaing pada PT. BPRS (Micro Banking Syariah) Niaga Madani di seluruh wilayah Sulawesi Selatan.

\section{METODOLOGI PENELITIAN}

\section{A. Pendekatan Penelitian}

Penelitian ini menggunakan pendekatan secara kuantitatif. Metode ini akan menitiberatkan pada pengujian hipotsesis dengan menggunakan data terukur yang selanjutnya dapat ditarik sebuah kesimpulan.

\section{B. Populasi dan Sampel}

Populasi adalah kumpulan individu atau obyek penelitian yang memiliki kualitas-kualitas serta ciri-ciri yang telah ditetapkan. Berdasarkan kualitas dan ciri tersebut, populasi dapat dipahami sebagai sekelompok individu atau obyek pengamatan yang minimal memiliki satu persamaan karakteristik (Cooper dan Emory, 1998). Penelitian ini adalah penelitian populasi. Sedangkan populasi sasaran yang digunakan adalah pimpinan PT. BPRS (Micro Banking Syariah) Niaga Madani di seluruh wilayah Sulawesi Selatan. Berdasarkan data yang diperoleh, diketahui BPRS (Micro Banking Syariah) Niaga Madani di seluruh wilayah Sulawesi Selatan adalah 13 BPRS.

Jadi jumlah responden yang akan diambil tetap sebanyak populasi yaitu 26 bahwa direktur dan wakil direktur PT. BPRS (Micro Banking Syariah) Niaga Madani di seluruh wilayah Sulawesi Selatan.

\section{Teknik Analisis}

Data yang telah terkumpul selanjutnya dianalisis menggunakan teknik analisis statistik yaitu Multiple Regression Analyasis (MRA). Menurut (Iqbal Hasan, 2002).

$$
\begin{aligned}
& \text { Dimana : } \\
& \mathrm{Y}= \text { Keunggulan Bersaing } \\
& \mathrm{b}_{1}= \begin{array}{l}
\text { Koefisien regresi implementasi } \\
\text { strategi deferensiasi }
\end{array} \\
& \mathrm{b}_{2}= \begin{array}{l}
\text { Koefisien regresi pengamtan } \\
\text { lingkungan }
\end{array} \\
& \mathrm{X}_{1}= \text { Implementasi strategi deferensiasi } \\
& \mathrm{X}_{2}= \text { Pengamtan lingkungan } \\
& e=\text { Varians pengganggu } \\
& \text { Berdasarkan hasil analisis }
\end{aligned}
$$$$
\mathbf{Y}=\mathbf{a}+\mathbf{b}_{1} \mathbf{X}_{1}+\mathbf{b}_{2} \mathbf{X}_{2}+\ldots \ldots . . . e
$$

perhitungan dengan metode regresi linear berganda yang telah dilakukan, selanjutnya perlu dilakukan serangkaian pengujian untuk membuktikan hipotesis. Pengujian yang dimaksud adalah uji F dan uji t.

\section{- Uji statistik t}

Uji statistik $t$ pada dasarnya menunjukkan seberapa jauh pengaruh satu variabel independen secara individual dalam menerangkan variabel dependen.

Hipotesis nol (H0) yang hendak diuji adalah apakah suatu parameter $\left(\beta_{1}\right)$ sama dengan nol, atau $\mathrm{HO}:=0$ yang artinya adalah apakah suatu variable independen bukan merupakan penjelas yang signifikan terhadap variable dependen.

Hipotesis alternatifnya $\left(\mathrm{H}_{\mathrm{a}}\right)$, parameter suatu variabel tidak sama dengan nol, atau $\mathrm{H0}: \neq 0$ yang artinya adalah variabel tersebut merupakan penjelas yang signifikan terhadap variabel dependen (Kuncoro, 2001). 
Pengambilan keputusan dengan tingkat signifikansi $(\alpha)=0,05$ ditentukan sebagai berikut:

a. Jika tingkat signifikansi t hitung > 0,05 atau $t$ hitung $<\mathrm{t}$ tabel, maka $\mathrm{H} 0$ diterima.

b. Jika tingkat signifikansi t hitung < 0,05 atau $\mathrm{t}$ hitung $>\mathrm{t}$ tabel, maka H0 ditolak.

- Uji statistik F

Uji statistik $F$ pada dasarnya menunjukkan apakah semua variable bebas yang dimasukkan dalam model mempunyai pengaruh secara bersamasama terhadap variabel terikat. Hipotesis nol (H0) yang hendak diuji adalah apakah semua parameter dalam model sama dengan nol atau $\mathrm{H} 0: \beta_{1}=$ $\beta_{2}=\ldots \ldots=\beta_{\mathrm{k}}=0$ yang artinya adalah apakah semua variabel independen bukan merupakan penjelas yang signifikan terhadap variabel dependen.

Hipotesis alternatifnya $\left(\mathrm{H}_{\mathrm{a}}\right)$, tidak semua parameter simultan sama dengan nol, atau $\mathrm{H} 0: \beta_{1} \neq \beta_{2} \neq \ldots \ldots \neq$ $\beta_{\mathrm{k}} \neq 0$ yang artinya adalah semua variable independen secara simultan merupakan penjelas yang signifikan terhadap variabel dependen (Kuncoro, 2001).

Kriteria pengujian :

a. Jika tingkat signifikansi $\mathrm{F}>0,05$ atau $\mathrm{F}$ hitung < $\mathrm{F}$ tabel, maka $\mathrm{H} 0$ diterima.

b. Jika tingkat signifikansi $\mathrm{F}<0,05$ atau $\mathrm{F}$ hitung $>\mathrm{F}$ tabel, maka $\mathrm{H} 0$ ditolak.

\section{PEMBAHASAN}

Dalam pembahasan akan disajikan gambaran responden pada penelitian ini serta proses menganalisis data-data yang diberikan oleh responden tersebut untuk menjawab pertanyaan penelitian dan hipotesis yang telah diajukan.
Analisis data yang dipergunakan dalam penelitian ini adalah Multiple Regression Analyasis (MRA) selanjutnya perlu dilakukan serangkaian pengujian untuk membuktikan hipotesis. Pengujian yang dimaksud adalah uji $\mathrm{F}$ dan uji t.

Obyek penelitian yang ditetapkan adalah seluruh pimpinan unit kerja PT. BPRS (Micro Banking Syariah) Niaga Madani di seluruh wilayah Sulawesi Selatan. Berdasarkan data yang diperoleh, diketahui bahwa seluruh pimpinan unit kerja PT. BPRS (Micro Banking Syariah) Niaga Madani di seluruh wilayah Sulawesi Selatan, Sulawesi Selatan yang dapat dijadikan responden adalah sebanyak 26 orang. Dari pengumpulan data dilapangan, diperoleh hasil bahwa 26 orang responden yang dikirimkan formulir kuesioner seluruhnya adalah direktur dan wakil direktur PT. BPRS (Micro Banking Syariah) Niaga Madani di seluruh wilayah Sulawesi Selatan dan seluruh kuesioner yang dikumpulkan dari responden tersebut semuanya telah diisi dengan lengkap dan dikirim dengan amplop tertutup disamping itu adanya penjelasan tambahan dari beberapa responden yang kami hubungi per telepon. Dengan demikian persyaratan untuk menjadi responden terpenuhi dan data kuesioner tersebut dapat digunakan untuk proses analisis selanjutnya.

Analisis data yang dilakukan oleh peneliti adalah uji reliabilitas, dan uji validitas dilanjutkan dengan analisis regresi linier berganda, koefisien determinasi, uji $\mathrm{F}$, dan uji $\mathrm{t}$ dengan menggunakan bantuan program statistik SPSS Versi 16.0.

\section{A. Uji Validitas}

Perhitungan dengan bantuan program SPSS menghasilkan uji validitas yang diujikan pada beberapa variabel yang digunakan yaitu $\mathrm{X}_{1}$ (implementasi strategi deferensiasi), $\mathrm{X}_{2}$ (pengamtan lingkungan), dan $\mathrm{Y}$ (Keunggulan Bersaing) dimana jika nilai korelasi 
memiliki signifikansi di bawah 0,05 uji validitas berdasarkan penelitian yang menunjukkan bahwa variabel tersebut telah dilakukan:

valid. Berikut ini merupakan tabel hasil

Tabel 1. Hasil Pengujian Validitas

\begin{tabular}{|l|l|c|c|c|}
\hline No & \multicolumn{1}{|c|}{ Indikator } & Korelasi & sig & Keterangan \\
\hline $\mathbf{1}$ & Implementasi strategi deferensiasi $\left(\mathbf{X}_{1}\right)$ & & & \\
& a. Indikator 1 & 0,672 & 0,000 & Valid \\
& b. Indikator 2 & 0,795 & 0,000 & Valid \\
\hline $\mathbf{2}$ & Pengamtan lingkungan $\left(\mathbf{X}_{2}\right)$ & 0,741 & 0,000 & Valid \\
& a. Indikator 1 & 0,652 & 0,000 & Valid \\
& b. Indikator 2 & 0,589 & 0,000 & Valid \\
\hline $\mathbf{3}$ & c. Indikator 3 & & & \\
& Keunggulan Bersaing (Y) & 0,832 & 0,000 & Valid \\
& a. Indikator 1 & 0,824 & 0,000 & Valid \\
& b. Indikator 2 & 0,609 & 0,000 & Valid \\
\hline
\end{tabular}

\section{Sumber : Data primer yang diolah, 2012}

Berdasarkan Tabel $1 \mathrm{di}$ atas dapat alat untuk mengukur suatu kuesioner yang diketahui bahwa nilai korelasi yang merupakan indikator dari variabel atau dimiliki oleh semua variabel indikator konstruk (Ghozali, 2006), dalam memiliki tingkat signifikansi lebih kecil penelitian ini pengukuran reliabilitas dari 0,05 , sehingga dapat disimpulkan dilakukan dengan bantuan program SPSS semua item pernyataan tersebut adalah dengan menggunakan metode Cronbach's valid.

\section{Uji Reliabilitas}

Reliabilitas sebenarnya adalah Alpha, dimana kuesioner dikatakan reliabel jika nilai Cronbach's Alpha lebih besar dari 0,6 .

Tabel 2. Hasil Uji Reliabilitas

\begin{tabular}{|l|c|c|}
\hline \multicolumn{1}{|c|}{ Variabel } & Cronbach Alpha & Status \\
\hline Implementasi strategi deferensiasi & 0,817 & Reliabel \\
\hline Pengamtan lingkungan & 0,836 & Reliabel \\
\hline Keunggulan Bersaing & 0,857 & Reliabel \\
\hline
\end{tabular}

Sumber: Data primer yang diolah, 2012

Berdasarkan Tabel 2 dapat diketahui

Hasil analisis regresi adalah bahwa nilai dari Cronbach's Alpha pada berupa koefisien untuk masing-masing keseluruhan variabel yang digunakan variabel independent. Koefisien ini dalam penelitian ini lebih besar dari 0,6 sehingga seluruh pernyataan dalam setiap

variabel dapat dikatakan reliable.

diperoleh dengan cara memprediksi nilai variabel dependent dengan suatu persamaan

\section{Analisis Regresi Linier Berganda}

Tabel 3. Hasil Analisis Regresi Linier Berganda

\section{Coefficients $^{\mathbf{a}}$}

\begin{tabular}{|c|c|c|c|c|c|c|c|}
\hline \multirow{2}{*}{ Model } & \multicolumn{2}{|c|}{$\begin{array}{c}\text { Unstandardiaed } \\
\text { Coefficients }\end{array}$} & $\begin{array}{c}\text { Standardized } \\
\text { Coefficients }\end{array}$ & \multirow{2}{*}{$\mathrm{t}$} & \multirow{2}{*}{ Sig. } & \multicolumn{2}{|c|}{ Collinearitv Statistics } \\
\cline { 2 - 4 } & $\mathrm{B}$ & Std Error & Beta & $\mathrm{t}$ & VIF \\
\cline { 2 - 8 }
\end{tabular}




\begin{tabular}{|l|r|r|r|r|r|r|r|}
\hline 1 (Constant) & 3.371 & 1.134 & & 2.972 & .000 & & \\
Implementasi strategi deferensiasi & .412 & .051 & .738 & 8.115 & .000 & .752 & 1.305 \\
Pengamtan lingkungan & .375 & .065 & .469 & 5.720 & .000 & .785 & 1.394 \\
\hline
\end{tabular}

Sumber: Data primer yang diolah, 2012

a.Dependent Variable: variabel Keunggulan Bersaing

Berdasarkan tabel 3 di atas dapat sebesar 0,375, arti persamaan tersebut disimpulkan bahwa variabel Keunggulan dapat terlihat bahwa semua variabel bebas Bersaing dipengaruhi oleh dua variabel (Implementasi strategi deferensiasi, dan yang digunakan dalam penelitian yaitu Pengamtan lingkungan) berpengaruh Implementasi strategi deferensiasi, dan positif terhadap Keunggulan Bersaing, Pengamtan lingkungan sehingga berpengaruhnya variabel-variabel terbentuklah persamaan seperti berikut ketidakpuasan konsumen, dan kebutuhan ini:

$\mathrm{Y}=3,371+0,412 \mathrm{X}_{1}+0,375 \mathrm{X}_{2}$ mencari variasi secara positif terhadap

Keunggulan Bersaing mengandung arti Berdasarkan hasil persamaan bahwa dengan meningkatnya persepsi regresi dapat dijelaskan pengaruh masing- responden tentang variabel Implementasi masing variabel independent terhadap strategi deferensiasi, dan Pengamtan variabel dependent adalah sebagai berikut: lingkungan maka akan berpengaruh pada Hasil analisis dapat diketahui bahwa meningkatnya Keunggulan Bersaing variabel bebas atau independent yang paling berpengaruh adalah variabel 4. Koefisien Determinasi $\left(\mathbf{R}_{2}\right)$

Koefisien determinasi mengukur Implementasi strategi deferensiasi dengan seberapa jauh kemampuan model dalam nilai koefisien sebesar 0,412, kemudian menerangkan variasi variabel dependent. diikuti oleh variabel Pengamtan Berikut ini tabel koefisien determinasi lingkungan dengan nilai koefisien yang dihasilkan dalam penelitian:

Tabel 4. Model Summary

Model Summary ${ }^{\mathrm{b}}$

\begin{tabular}{|l|c|r|r|r|}
\hline Model & R & R Square & \multicolumn{1}{|c|}{$\begin{array}{c}\text { Adjusted R } \\
\text { Square }\end{array}$} & $\begin{array}{c}\text { Std. Error of the } \\
\text { Estimate }\end{array}$ \\
\hline 1 & $.715^{\mathrm{a}}$ & .693 & .582 & .53692 \\
\hline
\end{tabular}

a. Predictors: (Constant), variabel Pengamtan lingkungan, variabel Implementasi strategi deferensiasi b. Dependent Variable: variabel Keunggulan Bersaing

Sumber: Data primer yang diolah, 2012

Berdasarkan tabel 4 dapat 41,8\%) dijelaskan oleh sebab-sebab lain di diketahui bahwa besarnya adjusted $\mathrm{R}^{2}$ luar model.

adalah 0,582, hal ini berarti 58,2\% variasi 5. Uji Signifikansi Simultan (Uji F)

dari Keunggulan Bersaing dapat Uji F menunjukkan apakah semua dijelaskan oleh variasi dari kedua variabel variabel independent yang dimasukkan ke independent yaitu Implementasi strategi dalam model mempunyai pengaruh secara deferensiasi, dan Pengamtan lingkungan, bersama-sama terhadap variabel sedangkan sisanya $(100 \%-58,2 \%=$ dependent. Hasil perhitungan uji $\mathrm{F}$ adalah sebagai berikut:

Tabel 5. Hasil Uji Signifikansi Simultan (Uji Statistik F)

\section{ANOVA ${ }^{b}$}




\begin{tabular}{|ll|r|r|r|r|r|}
\hline Model & \multicolumn{1}{c|}{$\begin{array}{c}\text { Sum of } \\
\text { Squares }\end{array}$} & \multicolumn{1}{c|}{ df } & \multicolumn{1}{c|}{$\begin{array}{c}\text { Mean } \\
\text { Square }\end{array}$} & F & Sig. \\
\hline 1 & Regression & 132.215 & 2 & 41.894 & 10.642 & $.000^{\mathrm{a}}$ \\
& Residual & 42.683 & 23 & .852 & & \\
& Total & 174.898 & 25 & & & \\
\hline
\end{tabular}

a. Predictors: (Constant), variabel Pengamtan lingkungan, variabel Implementasi strategi deferensiasi b. Dependent Variable: variabel Keunggulan Bersaing

\section{Sumber: Data primer yang diolah, 2012}

Berdasarkan uji ANOVA atau uji statistik keunggulan bersaing atau dapat dikatakan $\mathrm{F}$ didapat nilai $\mathrm{F}$ hitung sebesar 10,642 bahwa variabel Implementasi strategi dengan tingkat probabilitas 0,000. deferensiasi, dan Pengamtan lingkungan Probabilitas yang jauh lebih kecil jika secara bersama-sama berpengaruh secara dibandingkan 0,05, maka model regresi signifikan terhadap variabel Keunggulan dapat digunakan untuk memprediksi Bersaing.

\section{Uji Signifikansi Pengaruh Parsial (Uji t)}

Tabel 6. Uji Signifikansi Pengaruh Parsial (Uji t)

\section{Coefficients $^{\mathrm{a}}$}

\begin{tabular}{|c|c|c|c|c|c|c|c|}
\hline \multirow[t]{2}{*}{ Model } & \multicolumn{2}{|c|}{$\begin{array}{c}\text { Unstandardiaed } \\
\text { Coefficients }\end{array}$} & \multirow{2}{*}{$\begin{array}{c}\text { Standardized } \\
\text { Coefficients } \\
\text { Beta } \\
\end{array}$} & \multirow[b]{2}{*}{$\mathrm{t}$} & \multirow[b]{2}{*}{ Sig. } & \multicolumn{2}{|c|}{ Collinearitv Statistics } \\
\hline & $\mathrm{B}$ & Std Error & & & & Tolerance & VIF \\
\hline 1 (Constant) & 3.371 & 1.134 & & 2.972 & .000 & & \\
\hline Implementasi strategi deferensiasi & .412 & .051 & .738 & 8.115 & .000 & .752 & 1.305 \\
\hline Pengamtan lingkungan & .375 & .065 & .469 & 5.720 & .000 & .785 & 1.394 \\
\hline
\end{tabular}

a. Dependent Variable: variabel Keunggulan Bersaing

Sumber: Data primer yang diolah, 2012

Uji $t$ menunjukkan seberapa jauh pengaruh satu variabel independen secara individual dalam menerangkan variasi variabel dependen. Berdasarkan Tabel 6 dapat diketahui bahwa masing-masing variabel independent memiliki tingkat signifikansi kurang dari 0,05. Hal ini berarti bahwa masing-masing variabel independent berpengaruh signifikan terhadap variabel dependent. Berikut ini dijelaskan hasil perhitungan uji t masingmasing variabel:

1. Variabel Implementasi strategi deferensiasi

Hasil uji t pada variabel Implementasi strategi deferensiasi menghasilkan $\mathrm{t}$ hitung sebesar 8,115 dan signifikansi sebesar 0,000. T hitung 8.115 > t Tabel yang nilainya 1,706 dengan tingkat signifikansi 0.000 kurang dari 0,05 , maka dapat diketahui bahwa hipotesis yang menyatakan Implementasi strategi deferensiasi berpengaruh positif terhadap Keunggulan Bersaing dapat diterima.

2. Variabel Pengamtan lingkungan Hasil uji signifikansi pengaruh parsial (uji t) pada variabel Pengamtan lingkungan menghasilkan $\mathrm{t}$ hitung sebesar 5,720 dengan tingkat signifikansi 0,000. T hitung 5,720 > t Tabel yang nilainya 1,706 dengan tingkat signifikansi $0,000<0,05$, maka dapat diketahui bahwa hipotesis yang menyatakan Pengamtan lingkungan berpengaruh positif terhadap Keunggulan Bersaing dapat diterima.

\section{KESIMPULAN}

Berdasarkan hasil penelitian, maka kesimpulan yaitu : 
1. F hitung sebesar 10.642 dengan angka signifikansi sebesar $0,000<0,05$ artinya secara bersama-sama variabel Implementasi strategi deferensiasi, dan Pengamtan lingkungan berpengaruh signifikan terhadap Keunggulan Bersaing, dengan demikian hipotesis yang menyatakan bawa secara simultan variabel independent berpengaruh signifikan terhadap variabel dependent terbukti.

2. Nilai adjusted $R$ square adalah sebesar 0,582 artinya variasi perubahan pada Keunggulan Bersaing yang dapat dijelaskan oleh variabel Implementasi strategi deferensiasi, dan Pengamtan lingkungan adalah sebesar 58,2\%, sedangkan sisanya sbesar $41,8 \%$ dijelaskan variabel lain yang tidak diteliti.

\section{SARAN}

Penelitian mendatang hendaknya melakukan replikasi penelitian untuk daerah penelitian yang lebih luas. Replikasi penelitian juga dapat dilakukan tidak terbatas pada perbankan, tetapi dapat diperluas ke bidang yang lain. Penelitian dengan menguji dan menambah variabel-variabel baru yang dipandang mempunyai pengaruh penting terhadap keunggulan bersaing dan kinerja perusahaan pada industri yang berbeda dan daerah yang lebih luas akan menjadi agenda penelitian berikutnya yang menarik untuk diteliti.

\section{DAFTAR PUSTAKA}

Beal, Reginald M., 2000. Competing Effectively,

Environment Scanning, Competitive Strategy and Organizational Performance in Small Manufacturing Firms. Journal of Small Business Management, January : $27-47$

Choo, Chun Wei, 1999. The Art of Scanning the Environment.
Bulletin of the American Society for Information Science, March : $21-47$

Cooper, Donald R., dan C. William Emory, 1998. Metode Penelitian Bisnis. Erlangga, Jakarta.

Coyne, Kevin P. 1997. Sustainable Competitive Advantage - What It Isn't. Journal of Strategy

Cross, Lisa. 1999. Strategy Drives Marketing Success. Graphic Arts Monthly 71 (2) : 96

Cravens, Davis W. 1996. Pemasaran Strategis (Terjemahan), Erlangga, Jakarta.

Dirgantara, Crown. 2001. Manajemen Stratejik, Konsep, Kasus, dan Implementasi, Grasindo, Jakarta.

Getz, Gary A. dan Frederick D. Sturdivant, 1989. The Nuts and Bolts of FormulatingDifferentiation Strategy. Planning Review 17 (5) : $4-9$

Ghozali, Imam. 2006. Aplikasi Analisis Multivariate Dengan Program SPSS. Semarang. Universitas Diponegoro

Hasan, Iqbal. 2002, Pointers: Metodologi Penelitian, Badan Penerbit Universitas Diponegoro, Makassar

Husain, Umar. 2002. Riset Pemasaran dan Perilaku Konsumen. Cetakan kedua, Gramedia Pustaka Utama, Jakarta.

Kuncoro, 2001, Metode Kuantitatif, Yogyakarta: AMP YKPN.

MacMillan, Ian C. dan Rita Gunther McGrath, 1997. Discovering New 
Points of Differentiation. Harvard Sugiyono, 2004. Statistik Untuk Business Review : 133 - 138 Penelitian, Alfa Beta : Bandung

Porter, Michael E., 1993. Keunggulan Sri W, Agustinus. 1996. Manajemen Bersaing - Menciptakan dan Strategik (Pengantar proses Mempertahankan Kinerja Unggul. Erlangga, Jakarta berpikir. Strategik), Binarupa Aksara, Jakarta.

Porter, Michael E., 2007. Strategi Xu, Xianzhong, and G. R. Kaye, 1995. Bersaing : Teknik Menganalisa Industri dan Pesaing, Erlangga, Building Market Intelligence Jakarta Systems for Environment Scanning. Logistics Information

Santoso dan Tjiptono. 2009. SPSS Mengola Data Secara Management, Vol 8 No.2 : 22-29

Profesional. Felix Komputindo, Jakarta 